\title{
Ecological changes in geological media and Siverskyi Donets River basin under the condition of goal mines flooding
}

\author{
Yevheniia Anpilova ${ }^{1 *}$, Yevhenii Yakovliev ${ }^{1,2}$, Rolf Petry $^{3}$, and Volodymyr Horbulin ${ }^{1,4}$ \\ ${ }^{1}$ Institute of Telecommunications and Global Information Space of NAS of Ukraine, Kyiv, Ukraine \\ ${ }^{2}$ State Institution "Institute of Environmental Geochemistry of NAS of Ukraine”, Kyiv, Ukraine \\ ${ }^{3} \mathrm{DMT} \mathrm{GmbH} \& \mathrm{Co} \mathrm{KG}$, Berlin, Deutschland \\ ${ }^{4}$ The National Academy of Sciences of Ukraine, Kyiv, Ukraine
}

\begin{abstract}
Complex economic, geological-technological state of coal mines and impact of the armed conflict factors (the breakdown of energy supply, objects of critical infrastructure, etc.) accelerated closure of coal mines by the method of "wet preservation" in particular. In most developed EU countries decommissioning of coal mines, which have great depth (up to 1,0-1,5 km) and areas of minefields, occurs according to the post-mining (PM) research and production complex, which is based on the scientific and technological activities regarding prevention of dangerous changes in the geological environment (GE) - subsidence of ground surface, lands flooding, emission of explosive and toxic gases as well as reduction of outflows of polluted water into the local river basins (RB) and the soil aquifer. Additionally, PM suggests some mining works turning into the hydraulic-filtration system of mine water retention at a depth of $250-350 \mathrm{~m}$ with a purpose of preventing pollution flow into the freshwater aquifers and river network, preserving regional aquitards, degassing of mountain surface. In general, the PM activities complex aims at maintaining the balance and protective potential of the GE as mineral and landscape basis of the biosphere, elimination of dangerous changes in ecological parameters of the hydrographical network. It is shown that new models of subsoil and water use, geological prospecting structure, scientific basis for permissible changes in GE and RB are required together with closure of "old" mining works (MW) and opening of new ones, improvement of the environment monitoring based on GIS technologies and Earth remote sensing.
\end{abstract}

\section{Introduction}

Market restructuring of the mining and industrial complex (MIC) of Ukraine has led to a significant increase of requirements to technic-economic and ecological-social parameters of the subsoil use. Critical acceleration (with the start of the armed conflict in 2014) of closure and liquidation of mines of Donbas mostly through "wet preservation" (auto-rehabilitation flooding) conditioned poor consideration of the object-territorial and regional changes in ecological parameters of the naturaltechnogenic geosystems (NTGS) "coal mining region geological environment" under the current socialeconomic and geopolitical conditions [1-15].

From our point of view, during the period of restructuring of the leading coal mining sectors (CMS Donbas, Lviv-Volyn coal basin, West Donbas, Dnipro brown coal basin) experience of EU countries (Great Britain, Germany, France, Poland, etc.) in creating a legal basis and substantiating the NGTS new state ecological safety parameters as a result of abnormal changes in ecological parameters of its leading element technogenic-geological system (TGS) "mining complex geological environment" has not been taken into consideration. It was mainly connected with uncontrolled flooding of most mines at insufficient consideration of the new ecological state of the geological environment (GE) as a result of restructuring its accumulated long-term changes within the boundaries of various NGTS of Donbas

[1-6, 9-14, 16-21, 23-25, 35].

Under these circumstances, substantiation and implementation of post-mining principles and technologies relate to significant difficulties as a result of gaps in ecology legislation as well as a big complex of accumulated and newly created irreversible and dangerous changes in the ecological state of the subsoil.

Taking the above-mentioned into consideration, we can conclude that further functioning of the coal mining of Donbas on the controlled and non-controlled territories is possible based on accelerated post-mining activities implementation to the subsoil use on separate areas with sufficient power of mine pumping at further mining of coal fields.

\section{Analysis of previous publications}

The mining industry is dynamic, with some resources being mined for centuries until reserves are depleted or

\footnotetext{
* Corresponding author: anpilova@ukr.net
} 
technical and market conditions change, as has been the case in the former communist countries after 1990.

In almost all known cases, the cessation of exploitation of mineral resources has led to a number of serious problems [36-49]. The problems are similar in all mining regions [44-60], and the research in this paper points out these facts.

Research experience of the Institute of Telecommunications and Global Information Space of the NAS of Ukraine shows that use of the GIS can facilitate a significant increase of reliability of estimates of the ecological-technogenic conditions of the NTGS "waste polygon-environmental constituents" on the condition of reduction of the geological environment defensive ability as a consequence of the mines and pits flooding [5, 19$34]$.

The main factors which define the ecological state of the Donbas coal mining sectors are:

- geomechanical and hydrogeofiltrational imbalance of the rock mass as a result of conducting mining works with the exemption of large volumes of mineral raw materials, formation of a significant amount of polluted underground water flow into the local river network (up to 800 million $\mathrm{m}^{3}$ per year) and greenhouse gas (up to 6 bln $\mathrm{m}^{3}$ per year), destruction of regional aquitards and development of non-watertight areas of technogenic fissuring;

- formation of mining and recycling waste;

- destruction of hydrogeological and hydrological conditions of the territory.

All the other factors (development of hazardous geological processes, pollution of the surface atmosphere, soil, loss of biodiversity, etc.) in most cases derive from these three factors $[1-9,17,18]$.

\section{The research results}

The biggest ecological-technogenic, social-economical and technogenic threats to the population occur when coal mining enterprises closure is ecologically imbalanced due to the accelerated flooding of coal minings, level rise and pollution of local underground and surface sources of drinking and economic water supply beyond the claim mine concessions, additional deformation of the land surface, increasing upward migration of polluted mineralized water and explosive and toxic gases (methane, radon, hydrogen sulfide, etc.), which is connected with the depletion of regional waterproof (low permeable) layers $[13,17,18,25]$. At that, soil pollution surface centres can get in the zone of active water exchange (industrial and domestic waste polygons), surface flow and groundwater, which can actively move to the rivers and expand the area of water ecological risk.

In practice, it can result in disabling surface and underground drinking water supply systems, flooding and destruction of housing and industrial objects and communication (including ecologically dangerous objects such as oil and gas pipelines, chemical enterprises, etc.), complicated conditions of agricultural activities. Uncontrolled development of these processes, which are mostly irreversible in the coal mining sectors of Ukraine, including the additional impact of the armed conflict complicating factors on the East, global climate change and so on can lead to an ecological disaster, consequences of which will be extremely long-term and regional (borderless).

At that, the analysis of long-term changes in the ecological parameters of various NGTS in Donbas allows concluding the leading impact under current conditions of the anthropization of the geological environment and the Siverskyi Donets river basin as a regional drain of the underground flow technogenic reformation.

The main factors of technogenic changes in ecological parameters of the GE and river basins (RB) in the Donbas region under the conditions of postmining are:

- chemical pollution of landscapes;

- significant lowering of the underground water level, undermining of surface water bodies (up to 600 cases with different level of the surface flow interception);

- highly mineralized aggressive mine water flow in the river system;

- accelerating exogenic geological processes (landslides, karst, flooding), development of the original ground subsidence and complicating the engineering-geological state of housing and industrial objects;

- decrease in engineering-seismic resistance of rock mass influenced by increase in mobility of rocks in the areas of their undermining by mining works, development of hydromechanical impulses, etc.;

- formation of a large amount of waste pits, which are also a source of water resources, ground and surface air pollution.

The most dynamic changes in ecological parameters of the geological environment and river basins in Donbas are connected with inflows of underground water into the coal minings, the overall flow level of which into the river network at a maximum development of mining works was $25,0 \mathrm{~m}^{3} / \mathrm{sec}(1990)$. At a regional amount of natural water resources equal to about $12,0 \mathrm{~m}^{3} / \mathrm{sec}$, it indicated active drainage of surface water sources and hydraulic interconnection between mines [58-60]. At an average salinity of mine water equal to about $3,6 \mathrm{~g} / \mathrm{dm}^{3}$, it conditions the outwash of salts mainly into the Siverskyi Donets river basin at a level of 2,7 mln tons per year, which significantly activates pollution of the transboundary river flow in the Don (at the territory of Russian Federation) and Azov sea basin.

In the context of the armed conflict surface water objects, first of all, those of the Siverskyi Donets river basin, which is the major source of drinking and economic water supply (40-80\% of local water consumption) have a significant threat of dangerous deterioration of the geological state.

Evaluation of the ecological state of the reserve sources of drinking and economic water supply of Donetsk and Luhansk regions population, on the controlled and non-controlled by the Ukrainian government territories, is extremely important, as it is conditioned by the active use of pollution vulnerable local 
dug wells, boreholes and reservoirs by the local population beyond the central water supply system.

The authors created an indicative scheme of carrying out express research in the given region, which allowed evaluating the most vulnerable section critical for the health and ecological safety.

An important component is defining the role of emerging technologies, use of contact, remote methods of monitoring and geoinformation technologies (GIS) in particular.

Based on the geodata integrated into GIS, authors built models of surface water pollution dynamics in the Siverskyi Donets river basin.

To build models of pollution space distribution and evaluation of surface water quality authors used geostatic methods that allowed receiving interpolation area of pollution level values and building relevant maps of surface water quality change probability in the whole basin and the territory overall.

Activation of technogenic changes in, first of all, the surface flow of Donbas, is influenced by undermining of 129 rivers and beams and 26 reservoirs ( $>683$ cases) caused by mining works as well as by continuous subsidence of the original surface on the territory up to 8000 sq. $\mathrm{km}$ in the area of impact of which there are up to 1000 different industrial and potentially dangerous objects (Fig. 1) [1, 13, 25].

A significant complication of the mines closure process creates up to 250 earlier flooded mines, hydraulically connected with the active ones. According to the current evaluation, total mining works exceed 2,3 $\mathrm{km}^{3}$ and contain up to $1,6 \mathrm{~km}^{3}$ of water which can significantly accelerate regional activation of flooding of cities and villages territories, migration of pollution into the surface and underground intakes and the river network, as well as increase threat of emergency water breakthrough into the active.

Additional above-mentioned evaluations allow concluding that transformation of water-ecological parameters of natural-technogenic geosystems (NTGS) "mining complex - underground and surface hydrosphere" in the context of current auto rehabilitation flooding of mines in Donbas has considerable complexity and uncertainty during the implementation of post-mining activities. It is mostly conditioned by the fact that areas of the underground water level rise 5-10 times and more exceed areas of mining works, thus forming dynamic reformation of levels and chemical composition of underground water and its flow into the hydrographical network.

In our view, under the current conditions of socialeconomical and ecological-technogenic restructuring of subsoil use in Donbas, the biggest water-ecological threats to health and safety of a large number of people in the region (more than 50\%) occur when mining enterprises are closed without a sufficient complex of protective and ecological-stabilizing activities. Taking into consideration a spatial-temporal structure of factors of the changes in ecological parameters of GE and the surface flow of Donbas, we have substantiated a scale of ecological impact of the coal industry zone post-mining initial phase on the state of life-supporting components of the environment (lithosphere, hydrosphere, etc.).

The authors' evaluations showed that in the biggest by area and depth of mining works region of Donbas ecologically critical consequences of the auto rehabilitation flooding of mines (so-called "wet preservation") are connected with the absence of a pumping-hydraulic system which should keep the underground water level on the ecologically optimal depth lower than the regionally permeable crust of weathering coal rocks (from the experience of the EU countries - 250-350 m.). The given approach excludes active lateral spreading of polluted and mineralized mine water and its flow into the overlying freshwater aquifers and surface streams.

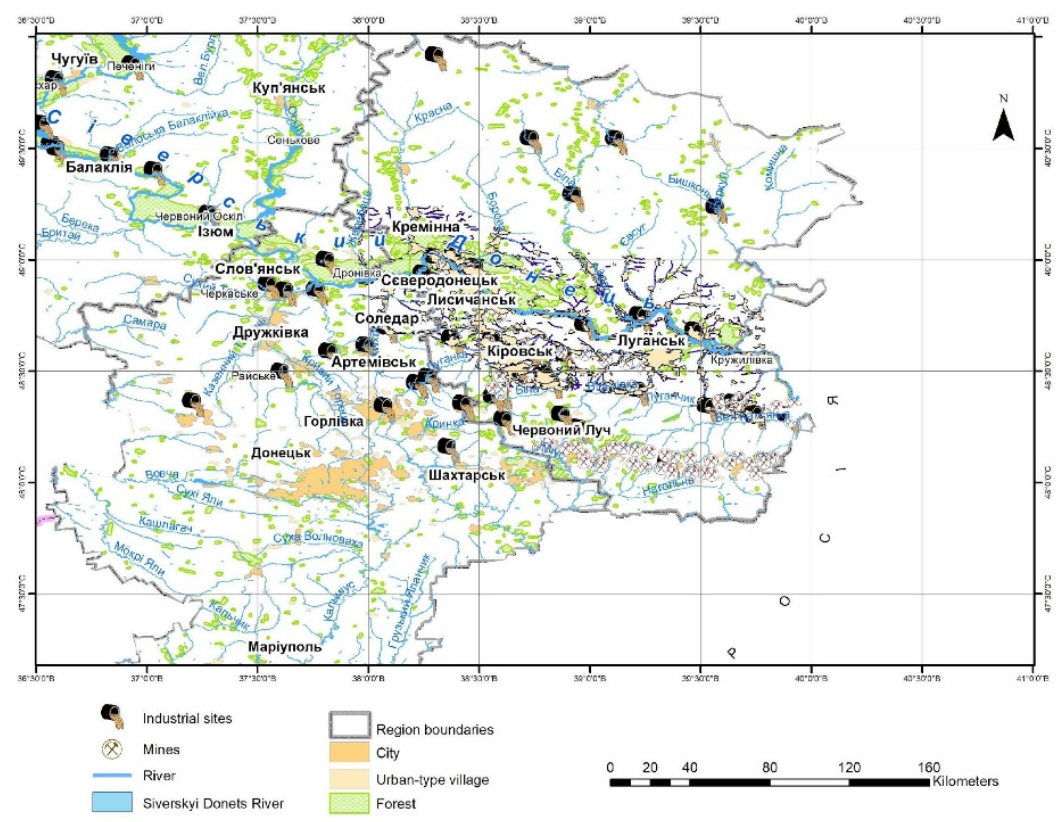

Fig. 1. Map of technogenic pressure on the Siverskyi Donets River Basin. 
The experience shows that at that, underground water level rise beyond the claim mine concession, additional surface subsidence, increasing migration of polluted mineralized water to underground and surface sources of water supply and explosive and toxic gases to housing and industrial buildings also occur in the most MW, which is mostly connected with tectonic and technogenic depletion of waterproof layers. The Fig. 2 shows the fundamental scheme of formation of underground and surface water flows interaction during the coal mine flooding in Donbas.

Taking into consideration the above-mentioned characteristics of interaction between the underground and surface water flows during the flooding of a coal mine in Donbas we have developed the "Scheme of the technogenic-geological system "mining complex geological environment" transition into the post-mining phase", is presented in Fig. 3.

The above-mentioned values show that disturbance of the balanced geomechanical state of the subsoil, level and hydrochemical mode of underground and surface water and deformation of the earth's surface in the context of auto rehabilitation flooding of mines ("wet preservation") are the main factors of development of potentially waterecological threats and risks of emergencies of waterecological nature.
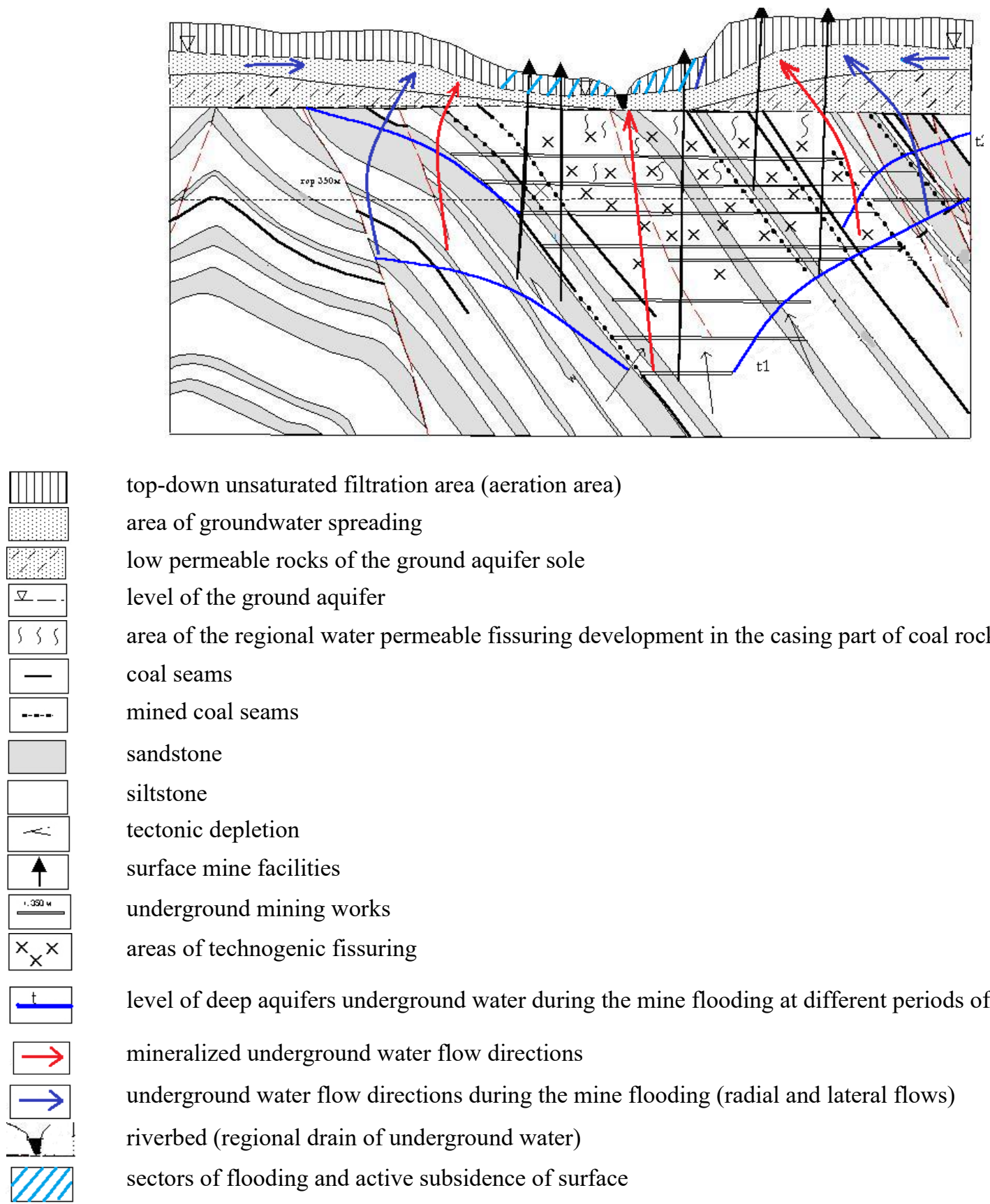

top-down unsaturated filtration area (aeration area)

area of groundwater spreading

low permeable rocks of the ground aquifer sole

level of the ground aquifer

area of the regional water permeable fissuring development in the casing part of coal rocks

coal seams

mined coal seams

sandstone

siltstone

tectonic depletion

surface mine facilities

underground mining works

areas of technogenic fissuring

level of deep aquifers underground water during the mine flooding at different periods of time

mineralized underground water flow directions

underground water flow directions during the mine flooding (radial and lateral flows)

riverbed (regional drain of underground water)

sectors of flooding and active subsidence of surface

Fig. 2. Fundamental scheme of formation of underground and surface water flows interaction during the coal mine flooding in Donbas. 
In general, results of the analysis of changes in the waterecological state of developed ("old") mining regions of Donbas considering critical technical-economical parameters of the natural resource potential achieved by them before the transition into the post-mining phase allow concluding possibility of partial realisation od correspondent activities on improvement of waterecological safety of vital activities.

Mainly it is connected with the irreversible disturbance of balanced natural interaction between the underground and surface components of the Donbas region hydrosphere as a result of exemption of large volumes of the coal mass followed by ruining regional aquitards and river valleys, subsidence of large areas of the earth's surface, geochemical pollution of surface and underground water-collecting landscapes, the collapse of host and casing rocks.

In that regard, in our opinion comparison of renewal levels of geological environment ecological-protecting functions (mostly ground and rocks of the aeration area) and surface hydrosphere (sediment) of the Chernobyl Exclusion Zone and the zone of the flooding of Donbas Central region mines are illustrative, is presented in Table 1.

Table 1. Comparison of changes in the ecological status of the geological medium of the Exclusion zones and the unconditional (obligatory) resettlement of the Chornobyl NPP and the impact area of the massive closure of mines in the Donbas (Influences levels: red - critical, yellow - dangerous, green - background).

\begin{tabular}{|l|c|c|}
\hline \multicolumn{1}{|c|}{$\begin{array}{c}\text { Types of changes in the } \\
\text { ecological condition of the } \\
\text { geological medium }\end{array}$} & Thochnogenic influence factors \\
\cline { 2 - 3 } $\begin{array}{l}\text { Landscape and geochemical } \\
\text { pollution }\end{array}$ & $\begin{array}{c}\text { Auto-rehabilitating cleanup (up to } \\
90 \% \text { by 2035) }\end{array}$ & $\begin{array}{c}\text { The area of impact of a large-scale } \\
\text { closure of the Donbas mines }\end{array}$ \\
\hline Lithospheric - equilibrium & No changes & Irreversible changes \\
\hline Hydrological & Short-term radionuclide pollution & Destructive changes \\
\hline Hydrogeological & Low concentrations of radionuclides & $\begin{array}{c}\text { Pollution and depletion of groundwater } \\
\text { resources }\end{array}$ \\
\hline Gas-geochemical & $\begin{array}{c}\text { Short-term contamination of the } \\
\text { atmosphere with radionuclides }\end{array}$ & $\begin{array}{c}\text { Increasing pollution of surface air pollution } \\
\text { geological conditions }\end{array}$ \\
\hline $\begin{array}{l}\text { Engineering-geological } \\
\text { Almost no changes in engineering- } \\
\text { geismic-engineering- }\end{array}$ & $\begin{array}{c}\text { Relatively stable condition } \\
\text { geogical }\end{array}$ & $\begin{array}{c}\text { Reduction of engineering and geological } \\
\text { stability }\end{array}$ \\
\hline
\end{tabular}

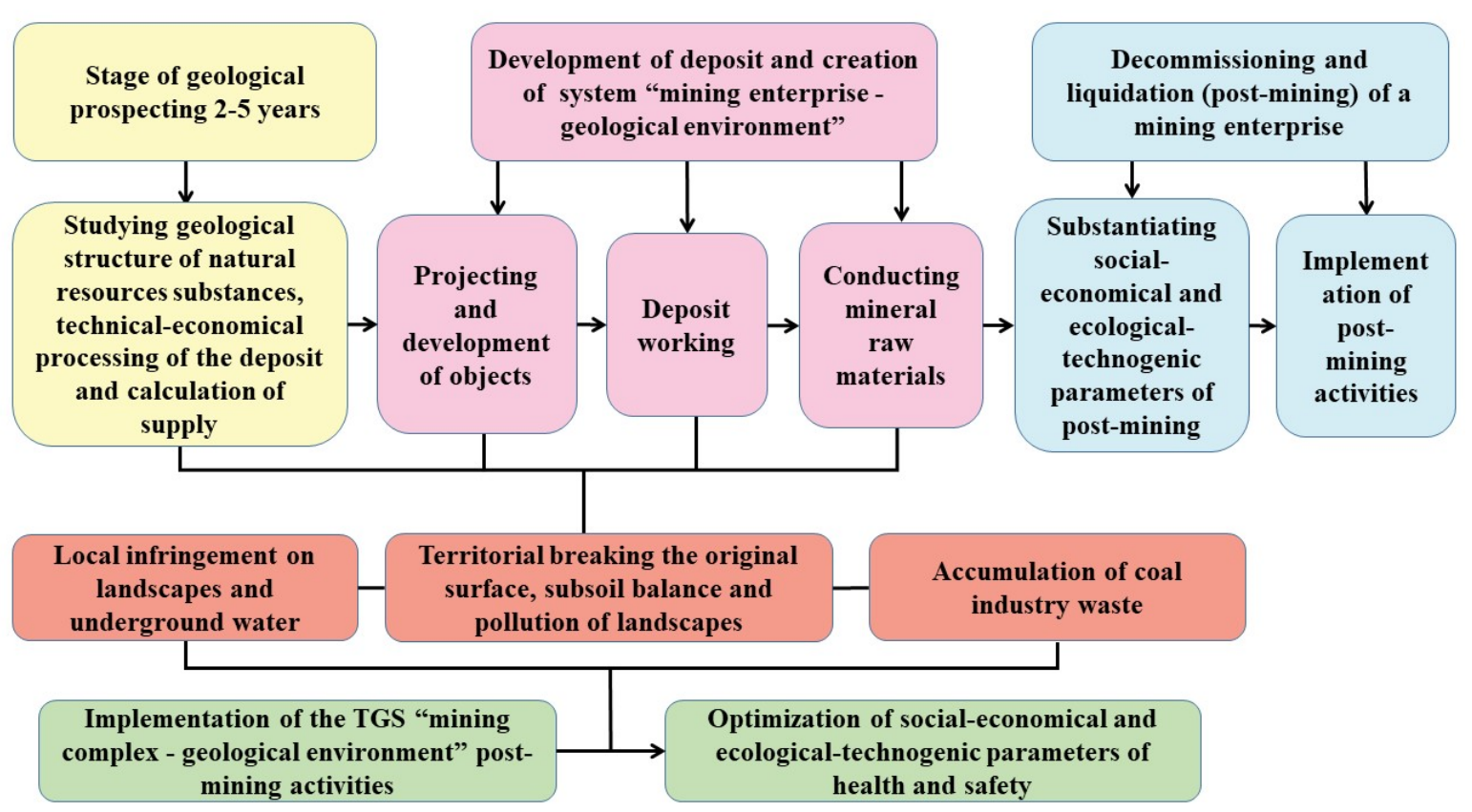

Fig. 3. Structural scheme of formation of the post-mining methodical base in the context of ecologically stable development of mineral raw materials deposits. 
Based on the data given in table 1 ecological state of the geological environment as a part of an NTGS is a crucial parameter of the natural resource potential renewal and formation of water-ecological factors of health and safety.

\section{Conclusions}

Based on the above-given evaluations a complex of ecological-technogenic and social-economical postmining activities in the most MS in Donbas can be partial, taking into consideration irreversibility of most changes in ecological parameters of a geological environment and surface hydrosphere, which have occurred or are at a stage of active development. At that, a large number of ecological functions of a geological environment (landscape-chemical, water-ecological, engineeringgeological, etc.) are lost in almost all developed CMS at the post-mining stage due to complex violations of the subsoil balance during exemption of large volumes of copper rock raw materials and creation of "lack of mass" in the upper zone of the lithosphere.

Thus, the main task of the post-mining separate activities implementation focused on the improvement of health and safety of the local population in the mining sectors of Donbas can be the following:

- improvement of forecasting the changes in main life-supporting components of the environment (ground, hydrosphere, subsoil, etc.);

- proactive development of a compensatory model of a stable social-economical and ecological-technogenic development of mining sectors in Donbas taking into account the restructuring mining complexes experience in the EU countries (Germany, Great Britain, etc.);

- improvement of the monitoring structure based on the broadening the complex of evaluating parameters, implementation om mathematical models of TGS in the mining sectors, use of the GIS and ERS technologies (interferometry, spectrometry and so on);

- scientific basis for permissible changes in the ecological parameters of the environment components and long-term health and safety;

- provision of long-term exploitation of the critical infrastructure objects (energy, water and heating supply complexes, transport network, etc.);

- increase in consumption of fresh underground water resources as a protected from technogenic pollution resource of drinking and economic water supply;

- definition of farmland sectors which are geochemically safe for receiving agricultural commodities.

In general, the stage of creating basis and developing the post-mining policy in the CMS in Donbas for the economics and a large number of people is a strategic scientific-technological and social-economical task, taking into account the leading role of a coal-raw component in contributing to the GDP and providing resource and energy safety of the country.

\section{References}

1. O. Trofymchuk, Y. Yakovliev, V. Klymenko, Y.
Anpilova, Geomodeling and monitoring of pollution of waters and soils by the earth remote sensing. International Multidisciplinary Scientific GeoConference - SGEM, 19, 1.4 (2019)

2. O.M. Trofymchuk, Yu.I. Kaliukh, V.A. Dunin, Y.A. Berchun. On the Possibility of Multi-Wavelength Identification of Defects in Piles. Cybernetics and Systems Analysis, 54 (2018)

3. I. Kaliukh, V. Senatorov, N. Marienkov, O. Trofymchuk, K. Silchenko, T. Kalyukh, Arrangement of deep foundation pit in restricted conditions of city build-up in landslide territory with considering of seismic loads of 8 points. Geotechnical Engineering for Infrastructure and Development - Proceedings of the XVI European Conference on Soil Mechanics and Geotechnical Engineering (2015)

4. R. Baum, T. Miyagi, S. Lee, O. Trofymchuk, Introduction: Hazard Mapping. Landslide Science for a Safer Geoenvironment (Springer, Cham, 2014)

5. O. Trofymchuk, Y. Kalyukh, H. Hlebchuk, Mathematical and GIS-modeling of landslides in Kharkiv region of Ukraine. Landslide Science and Practice: Spatial Analysis and Modelling (Springer, Berlin, 2013)

6. O.T. Azimov, I.V. Kuraeva, O.M. Trofymchuk, S.P. Karmazynenko, Ye.M. Dorofey, YuYu. Voytyuk, Estimation of the heavy metal pollution for the soils and different environmental objects within the solid domestic waste landfills. Conference Proceedings, 18th International Conference on Geoinformatics Theoretical and Applied Aspects (2019)

7. A.M. Gomilko, N.S. Gorodetskaya, A.N. Trofimchuk, Harmonic vibrations of a rigid impervious punch on a porous elastic base. International Applied Mechanics, 35 (1999)

8. O. Trofymchuk, I. Kaliukh, K. Silchenko, V. Polevetskiy, V. Berchun, T. Kalyukh, Use accelerogram of real earthquakes in the evaluation of the stress-strain state of landslide slopes in seismically active regions of Ukraine. Engineering Geology for Society and Territory - Volume 2 (Springer, Cham, 2015)

9. O. Trofymchuk, Yu. Kalyukh, I. Trofimova, H. Hlebchuk, Modelling of Landslide Hazards in Kharkov Region of Ukraine Using GIS. Landslides: Global Risk Preparedness (Springer, Berlin, Heidelberg, 2013)

10. A.M. Gomilko, A.N. Trofimchuk, Asymptotic Solution of Contact Harmonic Problem for an Impenetrable Stamp on a Poroelastic Base. International Journal of Fluid Mechanics Research, 28, 1-2 (2001)

11. A.N. Trofimchuk, Unsteady Oscillations of a LiquidSaturated Poroelastic Soil Layer. International Journal of Fluid Mechanics Research, 29, 1 (2002)

12. I. Kaliukh, O. Trofymchuk, G. Farenyuk, O. Ivanik, S. Shekhunova, Practical measures fo landslide risk mitigation in the Ukrainian Carpathians. First EAGE 
Workshop on Assessment of Landslide and Debris Flows Hazards in the Carpathians (2019)

13. O. Trofymchuk, O. Kolodyazhnyy, E. Yakovlev, Hazardous activation of landslides within Western Carpathian Region (Ukraine). Landslide Science for a Safer Geoenvironment (Springer, Cham, 2014)

14. O.M. Trofymchuk, V.M. Trysnyuk, V.O. Okhariev, Environmental security management of geosystems. 18th International Conference on Geoinformatics Theoretical and Applied Aspects, Extended Abstracts (2019)

15. A.N. Trofimchuk, V.A. Vasyanin, Simulation of packing, distribution and routing of small-size discrete flows in a multicommodity network. Journal of Automation and Information Sciences, 47, 7 (2015)

16. M. Myrontsov, O. Karpenko, O. Trofymchuk, V. Okhariev, Y. Anpilova, Increasing vertical resolution in electrometry of oil and gas wells. Systems, decision and control in energy II. Studies in systems, decision and control. (Springer, Cham, 2021), (to be published)

17. O. Trofymchuk, Y. Yakovliev, Y. Anpilova, M. Myrontsov, V. Okhariev, Ecological situation of post-mining regions in Ukraine. Systems, decision and control in energy II. Studies in systems, decision and control. (Springer, Cham, 2021), (to be published)

18. O. Trofymchuk, M. Myrontsov, V. Okhariev, Y. Anpilova, V. Trysnyuk, Transdisciplinary analytical system for support the environmental researches. Systems, decision and control in energy II. Studies in systems, decision and control (Springer, Cham, 2021), (to be published)

19. M.L. Myrontsov, O.M. Karpenko, O.M. Trofymchuk, V.O. Okhariev, Examples of determination of spatial and geoelectric parameters of productive beds of deposits of the Dnipro-Donetsk depth. XIV International Scientific Conference "Monitoring of Geological Processes and Ecological Condition of the Environment", Extended Abstracts (2020)

20. A. Greben, O. Trofymchuk, V. Trysnyuk, G. Krasovskiy, Interpretation of remote sensing data for ecological tasks. 2020 IEEE Ukrainian Microwave Week (UkrMW): 10th International Kharkiv Symposium on Physics and Engineering of Microwaves, Millimeter and Submillimeter Waves (21-25 September, Kharkiv, Ukraine), 3 (2020)

21. V.M. Trysnyuk, K.V. Smetanin., T.V. Trysnyuk, Y.V. Holowan, O.L. Kashchishin, K.O. Radlowska, The improvement of the system of ecological monitoring of the environment through the application of remotely piloted aircraft systems. XIII International Scientific Conference "Monitoring of Geological Processes and Ecological Condition of the Environment", Extended Abstracts (2019)

22. V. Trysnyuk, T. Trysnyuk, V. Okhariev, V. Shumeiko, A. Nikitin, Cartographic model of
Dniester river basic probable flooding. Geology and Environmental Engineering, D 22, 1 (2018)

23. V. Trysnyuk, O. Demydenko, K. Smetanin., A. Zozulia, Improvement of the complex evaluation method of vital activity risks. 19th International Conference Geoinformatics - Theoretical and Applied Aspects, Extended Abstracts (2020)

24. V. Trysnyuk, V. Prystupa, T. Trysnyuk, V. Vasylenko, A. Kurylo, Comprehensive environmental monitoring based on aerospace and ground research data. 19th International Conference Geoinformatics - Theoretical and Applied Aspects, Extended Abstracts (2020)

25. V. Trysnyuk, V. Okhariev, Y. Anpilova, T. Trysnyuk, Y. Nagorny, Environmental monitoring based on aerospace and terrestrial researches. XIV International Scientific Conference "Monitoring of Geological Processes and Ecological Condition of the Environment", Extended Abstracts (2020)

26. V. Romanyuk, V. Trysnyuk, M. Pidhorodetskyi, A. Nikitin. The mathematical formulation of the scientific problem of liquidation of consequences of natural and man-caused catastrophes on the territory of Ukraine. Polish journal of science, 1, 31 (2020)

27. O. Karpenko, M. Myrontsov, I. Karpenko, V. Sobol, Detection conditions of gas-saturated layers by the result of complex interpretation of non-electrical well logging data. XIV International Scientific Conference "Monitoring of Geological Processes and Ecological Condition of the Environment", Extended Abstracts (2020)

28. M.L. Myrontsov, Electrometry effective inverse problem solving method. 19th International Conference Geoinformatics - Theoretical and Applied Aspects, Extended Abstracts (2020)

29. M.L. Myrontsov, Lateral logging sounding and lateral logging complex effective inverse problem solving method. 19th International Conference Geoinformatics - Theoretical and Applied Aspects, Extended Abstracts (2020)

30. M.L. Myrontsov, Multi-Probe Hardware for Electrometry of Oil and Gas Wells. Science and innovation, 14, 3 (2018)

31. M.L. Myrontsov, Lateral logging sounding and lateral logging complex effective inverse problem solving method. 19th International Conference Geoinformatics - Theoretical and Applied Aspects, Extended Abstracts (2020)

32. M.L. Myrontsov, A new method and program for multiprobe electric logging quantitative interpretation. Geoinformatics $2012 \quad$ - 11th International Conference on Geoinformatics: Theoretical and Applied Aspects, Extended Abstracts (2012)

33. M.L. Myrontsov, The method to research equivalent solutions zones for inverse problem of well logging electrometry. XIII International Scientific Conference "Monitoring of Geological Processes and 
Ecological Condition of the Environment", Extended Abstracts (2019)

34. M.L. Myrontsov, The method to solve the inverse problem of lateral logging sounding and lateral logging. XIII International Scientific Conference "Monitoring of Geological Processes and Ecological Condition of the Environment", Extended Abstracts (2019)

35. Ju. N. Gavrilenko, V. N. Ermakov, O. A. Ulickij et al., Technogenic consequences of the coal mines closure in Ukraine (Donetsk, Nord-Press, 2004)

36. P. Ache, Cities in Old Industrial Regions Between Local Innovative Milieu and Urban Governance Reflections on City Region Governance. European Planning Studies, 8, 6 (2000)

37. H. Albrecht, Industrial Landscape and World Heritage Project "Montanregion Erzgebirge". TICCIH Congress Terni-Roma, (2006). (Available at:

http://www.ticcihcongress2006.net/paper/Paper\%20 B/Albrecht $\% 20 B . p d f)$

38. B. Dale, An Institutionalist Approach to Local Restructuring: The Case of Four Norwegian Mining Towns. European Urban and Regional Studies, 9, 1 (2002).

39. K. Eckart, et al., Social, economic and cultural aspects in the dynamic changing process of old industrial regions. Ruhr District (Germany), Upper Silesia (Poland), Ostrava Region (Czech Republic), (Münster, LIT Verlag, 2003)

40. G. Gorzelak, Regional Development and Planning in East Central Europe. In Kean, M (ed.): Regional Development and Employment Policy. Lessons from Central and Eastern Europe (Geneve, ILO, 1998)

41. M. O. White, Regional Innovation and Regeneration - An Irish Experience. In Good (Best) Practice Cases in Regional Development after Mining and Industry. Grazer Schriften der Geographie und Raumforschung (Universität Graz, 2007)

42. P. Wirth, G. Lintz, Rehabilitation and development of mining regions in Eastern Germany - Strategies and outcomes. Moravian Geographical Reports, 14, 2 (2006)

43. N. Kirkwood, Manufactured Sites. Rethinking the Post-Industrial Landscape (1st ed., London, New York, Taylor \& Francis, 2001)

44. P. McManus, Mines, Wines and Thoroughbreds: Towards Regional Sustainability in the Upper Hunter, Australia, Regional Studies, 42, 9 (2008)

45. J. Ježek, Mining Regions and Development Strategies in the Czech Republic. In Good (Best) Practice Cases in Regional Development after Mining and Industry. Grazer Schriften der Geographie und Raumforschung (Universität Graz, 2007)

46. J. Harfst, P. Wirth, C. Bieberstein, Strenghts, Weaknesses, Opportunities and Threats of European
Mining Regions (SWOT Report I), Output 3.3.1 (Dresden, Leibniz Institute of Ecological and Regional Development, 2010)

47. B. Müller, M. Finka, G. Lintz, Rise and Decline of Industry in Central and Eastern Europe (Berlin: Springer, 2005)

48. S. J. Rey, M. V. Janikas, Regional convergence, inequality, and space. Journal of Economic Geography, 5, 2 (2005)

49. M. Steiner, From Old Industries to New Regions: Policies for Structural Transformation in Accession Countries 1st ed., (Leykam, 2003)

50. P. Wirth, G. Lintz, Strategies of Rehabilitation and Development in European Mining Regions. Grazer Schriften für Geographie und Raumforschung, 42 (2007)

51. F.M. Zimmermann, J. Pizzera, S. Janschitz, The role of actors in regional development. In Good (Best) Practice Cases in Regional Development after Mining and Industry (Grazer Schriften für Geographie und Raumforschung, 2007)

52. P. Healey, Collaborative Planning: Shaping Places in Fragmented Societies (Univ. of British Columbia Pr., 1997)

53. R. Hudson, Rethinking change in old industrial regions: reflecting on the experiences of North East England. Environment and Planning A, 37, 4 (2005)

54. G. Pearman, 101 Things to Do with a Hole in the Ground (Eden Project, 2009)

55. A. Kaufmann, F. Tödtling, Systems of Innovation in Traditional Industrial Regions: The Case of Styria in a Comparative Perspective. Regional Studies, 34, 1 (2000)

56. L. Jolliffe, M. Conlin, Lessons in transforming mines into tourism attractions. In Mining Heritage and Tourism: A Global Synthesis. Routledge Advances in Tourism (Oxon, New York, Routledge, 2011)

57. Z. Karancsi, L. Mucsi, Human impact on the Medves region, N-Hungary. Zeitschrift für Geomorphologie, 41, 8 (1997)

58. N.H. Liuta Ekolohichnyi stan dovkillia ta yevropeiski perspektyvy Ukrainy. Ecological state of the environment and European prospects of Ukraine. Mineral resources of Ukraine, 1 (2011)

59. I.V. Udalov Transformation of the geological environment under the influence of man-made processes (in the conditions of the north-eastern Donbass) (Kharkiv, KhNU. Karazina, 2016)

60. S.S. Grebenkin, V.N. Ermakov, O.A. Ulitskiy, Geomechanical and technological problems of mines closing of Donbass (Donetsk, DonNTU, 2002) 